\title{
Memória e imaginação em Jean-Luc Lagarce
}

Marcelo LAZZARATTO ${ }^{1}$

Universidade Estadual de Campinas - Unicamp

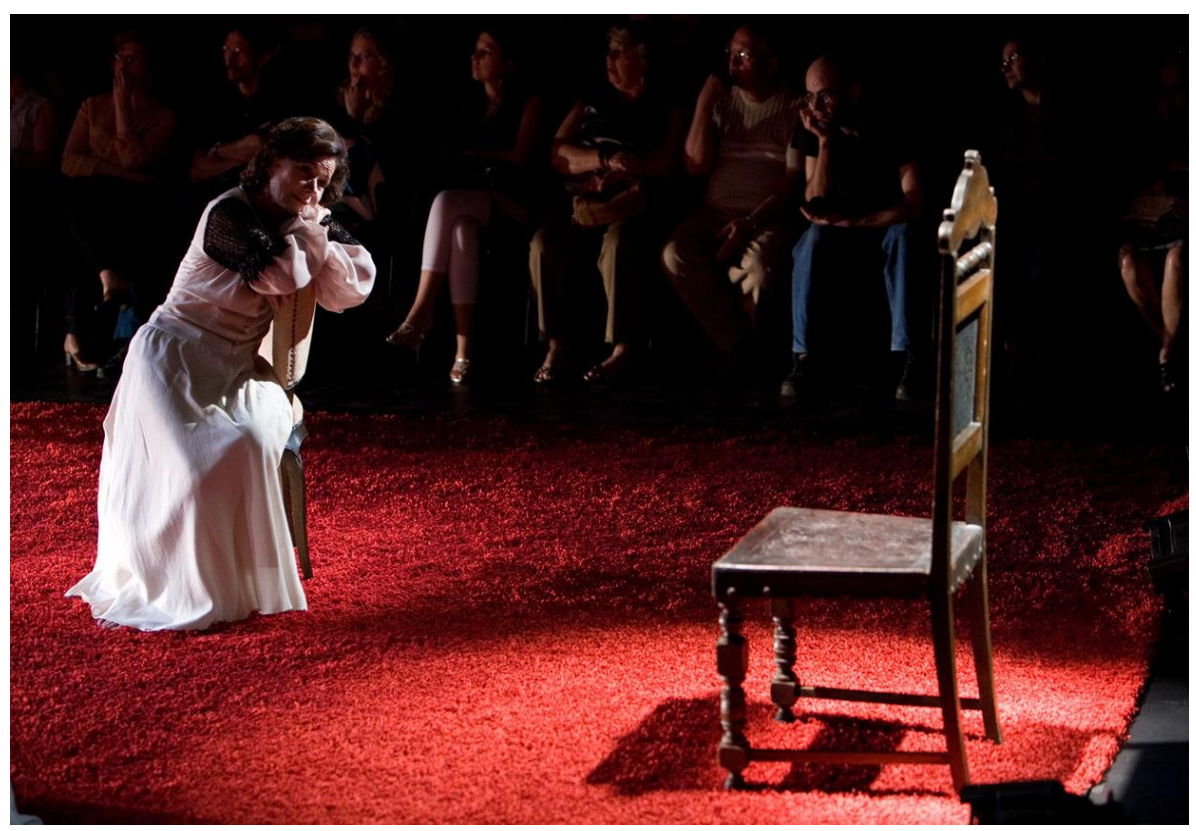

Miriam Mehler como A Mais Velha de Todas a olhar a cadeira vazia do neto

No ano de 2007, dando continuidade à investigação sobre a linguagem cênica e, principalmente, à interioridade do ator e seus desdobramentos criativos, montei com a minha companhia de teatro, a Cia. Elevador de Teatro Panorâmico, "Eu estava em minha casa e esperava que a chuva chegasse", de Jean-Luc Lagarce. Esse espetáculo esteve em cartaz no SESC - Avenida Paulista em outubro/novembro de 2007, e de outubro a dezembro de 2010 no Espaço Elevador, quando das comemorações dos 10 anos da Cia. Elevador.

Convidamos as atrizes Miriam Mehler ( $1^{\mathrm{a}}$ temporada) e Daniela Alves ( $2^{\mathrm{a}}$ temporada) para interpretar o papel da Avó (a Mais Velha de Todas), e Grácia Navarro, para interpretar o papel da Mãe. As filhas foram interpretadas pelas atrizes da Companhia

\footnotetext{
${ }^{1}$ Marcelo Lazzaratto é ator, diretor e pesquisador teatral. Leciona no Depto. de Artes Cênicas da Unicamp e é diretor artístico da Cia. Elevador de Teatro Panorâmico. Publicou em 2011 o livro O Campo de Visão: exercício e linguagem cênica.E-mail: marevi@uol.com.br.
} 
Elevador de Teatro Panorâmico: Carolina Fabri (a Filha mais Velha), Marina Vieira (a Segunda) e Juliana Pinho (a Mais Nova).

Naquele momento, queríamos voltar nossos olhos para a interioridade do ator em busca da sua grande intimidade criativa, seu poder de imaginar. Compreender como se dá o transporte entre aquilo que foi imaginado e sua devida exteriorização em ação cênica.

Queríamos compreender os alicerces para a construção dessa ponte imaginária por onde se transubstancia o material poético subjetivo em material poético objetivo. Para isso, precisávamos, para melhor fundamentar nossa investigação, de um material dramatúrgico que trouxesse, em sua estrutura, as questões da memória e da imaginação criativa. E isso encontramos na dramaturgia de Jean-Luc Lagarce.

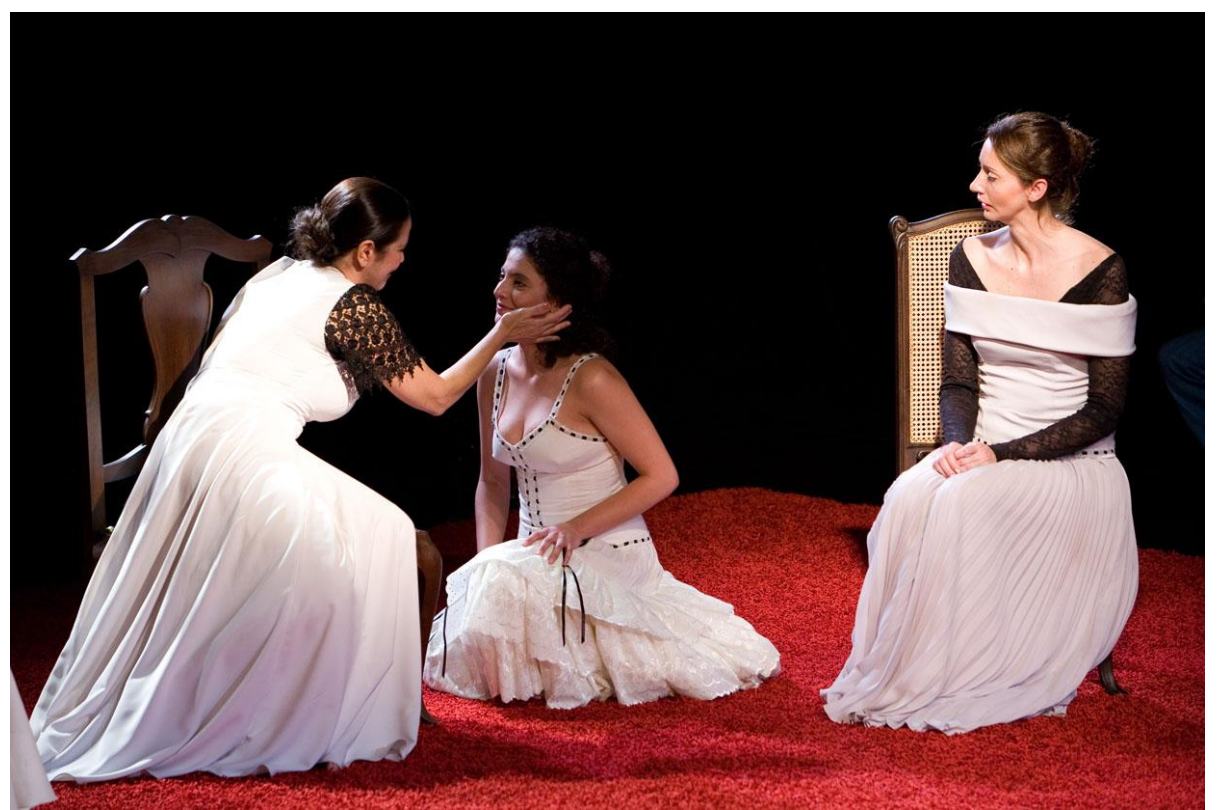

Gracia Navarro como A Mãe, Marina Vieira como A Segunda e Carolina Fabri como A Filha Mais Velha

Nos textos de Lagarce, o uso sistemático e aleatório dos fluxos de pensamento, memória e imaginação criativa servem como contraponto a uma realidade que a cada dia faz com que as personagens se sintam mais solitárias e presas nos próprios processos mentais de significação. Em muitos de seus textos, e 
nessa peça com grande intensidade, para seus personagens, suas memórias se tornam de fato realidade.

"Eu Estava em Minha Casa e Esperava que a Chuva Chegasse" é uma peça que trata do sentido da vida. Nela existem cinco mulheres que estão anos esperando a volta do filho/irmão e que encontraram nesta ausência uma razão de ser, uma razão de existir. A ausência dele e, principalmente, a expectativa da sua volta, fez com que elas fossem devoradas pela memória e pela imaginação. Ou seja, cada uma delas, ao seu modo, com suas características, imagina, lembra, divaga, pensa, cria mundos, possibilidades de existência que, para elas, são reais. Mas aqui os personagens de Lagarce, embora imaginem o tempo todo e até mesmo tenham consciência disso, pois verbalizam essa ideia, passaram anos confundindo imaginação com ilusão. De certo modo elas operam no autoengano.

A questão é: Lagarce, um autor influenciado por Beckett, amplia a tragédia beckettiana porque, ao contrário de Godot, que não aparece para Estragon e Vladimir², ele faz com que esta pessoa, este filho/irmão que vai dar sentido à vida delas, apareça. Só que ele não faz nada. Chega, cai no meio da sala e não sabemos se está vivo ou morto. Ele, quando a peça se inicia, está em seu quarto, parece que definhando. Isto faz com que um grande choque de realidade abale estas mulheres. Tudo que elas "imaginaram" que iria acontecer quando ele voltasse não acontece. A ilusão se quebra, e assim se estilhaça a esperança enganadora. Temos a sensação de ampliação do sentido trágico porque Lagarce, por alguns segundos, oferece a realização da esperança para em seguida aniquilá-la através de um gesto torpe e inerte.

\footnotetext{
${ }^{2}$ Em 2005 tive a felicidade de montar com a Boa Companhia Esperando Godot, de Samuel Beckett. Em todo o processo de montagem da peça de Lagarce escutava as palavras beckettianas reverberarem em meus ouvidos. Posso mesmo dizer que se trata de montagens complementares em meu processo de criação. Tanto no que diz respeito à temática quanto à espacialização e marcação cênicas por mim orquestradas.
} 
A peça acontece exatamente neste momento posterior à queda do filho. Ela na verdade é constituída de uma sequência de solilóquios, que algumas vezes dialogam entre si, em que as mulheres revelam todas as "imaginações", todas as lembranças, todas as criações, que elas fizeram a respeito dele e de sua volta.

Elas nos contam como para elas era a vida "antes dele partir para nunca mais voltar". Contam como haviam imaginado a vida com ele novamente. $\mathrm{E}$ aos poucos compreendemos quem são essas mulheres. Elas se revelam através de suas opções imaginadas. A maneira como organizam o material acessado na memória com o material advindo da imaginação revela seus temperamentos, seus traços de personalidade. É como se o "eu" de cada uma delas também fosse uma construção de linguagem apoiada em matéria humana profunda, suas lembranças.

Esses solilóquios aos poucos interagem um com o outro e então começamos a compreender como se dá a relação entre elas, quais as possíveis intrigas familiares, o sentimento de culpa, as ameaças, os carinhos e afagos, a cumplicidade ao compreenderem que todas estão inevitavelmente fadadas a esperar e que isso não mudará.

Outra característica do texto que me parece importante ressaltar é o tempo da escuta, o tempo da fruição que cada personagem tem quando o outro discorre longamente sua narração, suas questões, seus devaneios. Esse tempo é um tempo longo. Trata-se de longos solilóquios. Há tempo suficiente para devanear. Tempo suficiente para recriar os caminhos que agora não encontram repouso. Quando a Mãe, por exemplo, começa a contar o que tinha imaginado, quando ela diz que necessitava da voz do filho, que mesmo antes, quando ele ainda vivia na casa, ela sempre sentia falta de suas palavras, e que essa dor ela não mais suporta sentir; as outras mulheres, ao escutar esse grande lamento materno, ativam seus processos mentais e associam, checam se o que a mãe conta confere com suas lembranças, estabelecem juízos de valor contundente, negam, afirmam, reinventam o que já 
tinham construído para satisfazer uma emoção que o momento, a voz e a dor da Mãe gerou. É como se a escuta em seu processo reativo também ativasse e resignificasse o mundo interior de cada personagem.

Nessas longas falas percebemos como cada uma criou um filho/irmão próprio. Porque nunca sabemos ao certo quem é esse homem. Ele não nos aparece. Não conhecemos sua realidade. Só o conhecemos a partir do olhar e da fala dessas mulheres. Talvez ele nem exista realmente. Lagarce, assim, denuncia que talvez a realidade como queiramos entender só exista em nossos processos mentais de significação. E como nos diz Godard, "a realidade talvez, nunca tenha se mostrado para ninguém". E temos, talvez, que nos satisfazer com isso.

Porque a vida continua a mesma. O ser humano sempre fica à espera que algo importante aconteça - e esta coisa importante até pode acontecer (na peça o filho/irmão retorna) mas isto não quer dizer que as coisas se transformarão objetivamente. Pois a expectativa sempre será diferente do fato. A expectativa é fruto de uma imaginação regida pela ilusão, e o fato é fruto do encontro de vários fatores que estão fora do controle do indivíduo, que estão além de seus processos de criação.

Hoje sabemos que a expectativa influencia significativamente as lembranças. Ela pode até distorcer o processo de codificação, armazenamento e recuperação de informações que são o tripé funcional da Memória. A expectativa, assim, pode fazer com que recordemos fatos que nunca ocorreram. Porque, ao recordar, o indivíduo reconstrói os estilhaços de lembranças e os reorganiza coerentemente de acordo com sua circunstância presente. O "modelo internalizado de expectativas sobre nós mesmos e sobre o mundo" (CALLEGARO, ano 1, $\mathrm{n}^{\mathrm{o}} 7, \mathrm{p} .37$ ) exerce uma força muito grande nesse processo de recriação, pois ele lançará mão de todo e qualquer expediente para que aquilo que o indivíduo lembra o satisfaça plenamente. 
Agora, se o indivíduo colocar-se no lugar de pura afecção, disponível aos encontros e trocas, intersecções e contaminações, ele compreenderá que as coisas são assim e seu sofrimento será menor, pois não se relacionará com as coisas a partir de suas expectativas e sim a partir da concreta experiência. E é exatamente isso que esses personagens de Lagarce não souberam fazer em suas vidas.

O texto de Lagarce começa com um longo solilóquio dito pela Filha mais Velha que, de certa maneira, como um prólogo, sintetiza tudo o que a peça almeja revelar. Ali encontramos a memória e a imaginação aliadas, encontramos estruturas frasais poéticas e repetitivas, uma dança dos tempos verbais e uma narrativa-lírica. Ou seja, Lagarce joga com os ingredientes da linguagem, para assim, mergulhar na intimidade da personagem. Por isso o separamos e escolhemos analisá-lo mais detalhadamente nesse artigo. Vamos a ele.

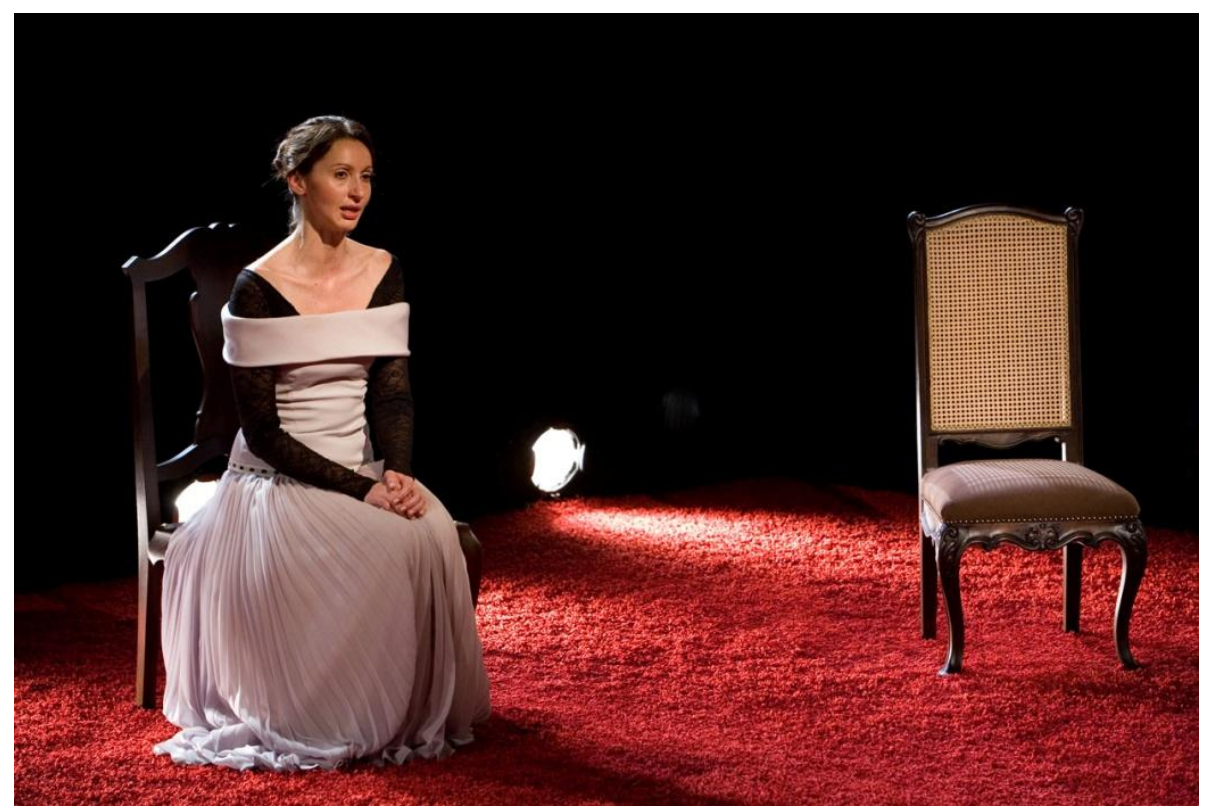

Carolina Fabri em um dos solilóquios da Filha Mais

Velha

A Filha Mais Velha

Eu estava em minha casa e esperava que a chuva chegasse. 
Eu olhava o céu como eu faço sempre, como eu sempre fiz,

Olhava o céu e olhava o campo ainda que vai descendo devagarzinho, deixando a nossa

casa para trás, e a estrada que desaparece ao desviar do bosque, lá longe.

Olhava, era de noite e é sempre de noite que eu fico olhando, sempre de noite que eu

passo horas ao pé da porta, olhando.

Eu estava aqui, em pé, como eu sempre estou, como eu sempre estive,

imagino isso,

eu estava aqui, em pé, e esperava que a chuva chegasse, que ela caísse sobre o campo, sobre as plantações, e sobre o bosque, e que ela nos acalmasse,

Esperava.

Será que eu nunca deixei de esperar?

(E na minha cabeça, ainda, ficava pensando nisso: será que eu nunca deixei de esperar? e isso me fez rir, rir de me ver assim.)

Olhava a estrada e pensava também, como eu penso sempre, à noite, quando eu fico ao pé da porta esperando que a chuva chegue,

ainda pensava nesses anos que nós tínhamos vivido aqui, assim todos esses anos,

nós, vocês e eu, nós cinco, como nós sempre estamos, e como nós sempre estivemos,

estava pensando nisso,

todos esses anos que nós tínhamos vivido e que nós tínhamos perdido,

porque foram anos perdidos,

todos esses anos que nós tínhamos passado à espera dele, do caçula, desde o dia em que ele partiu, fugiu, nos abandonou,

desde que o pai o expulsou daqui,

hoje, nesse dia preciso, eu estava pensando nisso, nesse dia preciso, eu estava pensando nisso,

todos esses anos que nós perdemos sem sair daqui, só à espera

( e ainda aí, parece, comecei, mais uma vez, a sorrir de mim mesma, de me ver assim,

de me imaginar assim, e sorrir assim de mim mesma à beira de lágrimas, e tive medo de afundar)

Todos esses anos que nós tínhamos vivido à espera dele e perdidas sem fazer outra coisa que não fosse esperar por ele, sem poder obter nada, nunca, sem ter outro objetivo que não fosse esse,

e eu pensava, nesse dia preciso, no tempo que eu poderia ter passado longe daqui, fugindo daqui, no tempo que eu poderia ter passado numa outra vida, num outro mundo,

ideia minha,

sozinha, sem vocês, as outras aí, sem vocês outras, todas,

todo esse tempo que eu poderia ter vivido diferentemente, simplesmente, 
sem esperar, sem esperar mais, ter me soltado de mim mesma.

Esperava a chuva, esperava que ela caísse, esperava, como, de um certo modo eu sempre esperei, esperava e eu o vi,

eu esperava e foi aí que eu o vi, esse daí o caçula, fazendo a curva do caminho e subindo em direção de casa, eu esperava sem esperar nada de preciso

e eu o vi voltar, esperava como eu espero sempre, há tantos anos, sem esperança de

nada, e foi nesse exato momento que ele apareceu, e que eu o vi.

Um carro vem deixá-lo e ele caminha os últimos cem metros, bolsa jogada sobre o ombro, em minha direção.

Olho para ele vindo em minha direção, em minha direção, em direção de casa.

Olho para ele.

Eu não me mexia, mas tinha certeza que seria ele, tinha certeza que era ele, ele entrava na nossa casa depois de todos esses anos, assim mesmo,

nós sempre tínhamos imaginado que ele voltaria assim, sem prevenir, sem festa de boas-vindas e ele fez o que nós sempre tínhamos imaginado que ele faria.

Ele olhava pra frente e caminhava calmamente sem se apressar mas parecia que não me via, esse daí, o caçula, por quem tanto esperei e perdi a minha vida esperando -perdi, sim, não tenho dúvida, e de uma maneira tão inútil, agora, a partir de agora, eu sei, que eu a perdi-

esse daí, o cacula, voltando das suas guerras, eu o vi enfim e em mim nada mudou, fiquei espantada com a minha própria calma, nenhum grito como eu tinha imaginado que eu daria, que vocês dariam, nossa versão das coisas, nenhum berro de surpresa ou de alegria, nada.

Eu via, ele andando em minha direção e pensava que ele estava de volta e que nada ia mudar na minha vida, que foi engano meu.

Solução nenhuma.

(...)

Em nossos ensaios, durante todo o percurso, eu e as atrizes, processamos o material subjetivo para transformá-lo em ação objetiva. O material subjetivo de cada personagem deveria encontrar correspondência com o material subjetivo de cada atriz. Não em uma mera associação de fatos que de alguma forma fossem correspondentes com os das personagens, não utilizamos a memória emotiva proposta por Stanislávski. Mas algo que se entrelaçasse em uma região mais funda, mais sensorial, uma 
correspondência de afetos, correspondência de estados psíquicos. Lugar em que a memória e a criatividade imaginativa individual entram em consonância com a memória e a criatividade imaginativa construída pela linguagem que Lagarce construiu para suas personagens. Porque sempre se tratará de um constructo criado em forma de linguagem.

As atrizes deveriam encontrar em si e além de si a mesma construção de linguagem que por sua vez o autor criou quando escreveu o texto. É como se Lagarce e sua imaginação entrassem em consonância com a imaginação de cada atriz e vice e versa. Porque para que a ação de cada uma delas se tornasse "viva" as fronteiras existentes entre a linguagem construída pelo autor e a compreensão anímica das atrizes deveriam deixar de existir.

Esse lançar-se para essa interioridade profunda é temeroso e muito difícil de realizar. A razão impõe muitos obstáculos para que isso aconteça. Sem um treinamento psíquico constante para fazer com que as válvulas da intuição se mantenham abertas, o ator certamente sucumbirá ao seu bom senso. O bom senso é um ingrediente que não faz parte do cardápio do artista. Mas para que o ator expresse um gesto artístico o caminho de volta desse mergulho arqueológico até a superfície é de suma importância.

Assim, em nossos ensaios de "Eu estava em..." analisamos os códigos de linguagem sobre os quais Lagarce estruturou seus personagens. Eu e as atrizes precisávamos compreender que a rigidez formal imposta pelo autor era compatível com o material subjetivo, escorregadio, fugidio de suas memórias e imaginações. Se a primeira vista pareciam contrários e antagonistas, depois entendemos de sua profunda aliança em prol da expressão artística.

Analisemos então uma sequência de construção frasal de Lagarce:

Eu estava em minha casa e esperava que a chuva chegasse. 
Eu olhava o céu como eu faço sempre, como eu sempre fiz,

Olhava o céu e olhava o campo ainda que vai descendo devagarzinho, deixando a nossa

casa para trás, e a estrada que desaparece ao desviar do bosque, lá longe.

Olhava, era de noite e é sempre de noite que eu fico olhando, sempre de noite que eu passo horas ao pé da porta, olhando.

Lagarce começa o texto em chave narrativa. Uma primeira pessoa nos conta que ela estava em sua casa e esperava que a chuva chegasse. E o tempo passado é o tempo mais empregado em sua narração de um fato que já aconteceu. Mas a insistência da primeira pessoa e as imagens advindas das sensações subjetivas descritas por ela, e que na verdade a atravessaram, rapidamente nos tiram de uma narrativa convencional e nos colocam em contato com uma estrutura em que o gênero é impuro. Ou seja, o texto de Lagarce se constrói tendo como base uma narrativalírica, em que o "eu" subjetivo e o fato narrado se entrelaçam e se redimensionam. Aos poucos, conforme a peça discorre e os outros personagens contam através de seus "eus", começamos a perceber que talvez o fato narrado pode não ter acontecido de fato, ou que de fato aconteceu apenas em suas mentes abaladas.

Se a narração é o gênero empregado, então a memória é peça fundamental para o processo. Eu conto porque eu lembro. Ao me lembrar me defino e reforço minha identidade. É por esse caminho que começamos a conhecer as personalidades das personagens. Quando lembram, seus eus selecionam e escolhem aquelas lembranças que são pertinentes a eles. $\mathrm{Na}$ verdade o eu se lembra muitas vezes daquilo que ele quer lembrar e não necessariamente de todo o ocorrido. A maneira pela qual a personagem escolhe suas lembranças nos revela sua identidade não pelos fatos lembrados em si, mas pelo modo como ela os reencadeou ${ }^{3}$. Ela revela os bloqueios que seu "eu" cria para que ela não tenha acesso novamente à experiência vivenciada.

\footnotetext{
${ }^{3}$ Para ser e perceber-me como indivíduo é necessário lembrar. "Lembro, logo existo", dizem hoje os cientistas que estudam a memória dizendo mais: "...de
} 
Percebemos isso aos poucos, quando ouvimos a mesma história contada por cada personagem. Cada uma conta sua lembrança utilizando meios definidos pelo eu. Ele seleciona aquilo que melhor lhe convém, que justifica sua expectativa, que não o coloca em risco. Escutamos suas impressões, nunca escutamos a verdade do fato, se é que há verdade em alguma coisa.

Mas ao mesmo tempo Lagarce enche os nossos olhos da imaginação ao fazer com que sua personagem olhe e nos descreva a paisagem que circunda sua casa. Já a primeira frase, que é o título da peça, guarda em si uma forte carga poética. A primeira pessoa em sua casa esperando pela chuva. Acolhida em sua casa (sua primeira pessoa, seu eu) ela anseia pela chuva, talvez pelas gotas que refresquem sua inquietação, talvez ela espere pela tormenta que sacuda sua casa e sua inércia. Chuva que possa de novo fertilizá-la com sua água abundante e seminal.

E em seguida ela nos descreve sua região. Parece que ela mora em uma casa que se encontra afastada da urbe. Ela olha o céu, o campo, a estrada que desaparece no bosque, "lá longe"... Nossa personagem está em um território amplo, vasto. Será essa imagem um reflexo de sua interioridade, da interioridade dessas cinco mulheres que esperam seu homem? Será que elas esperam que ele chegue e invada sua morada habitada apenas por lembranças e imaginações? Poderíamos seguir adiante em uma análise psicanalítica se aqui fosse o lugar adequado para isso, mas como esse terreno é um terreno arqueológico prefiro que as imagens sejam indícios de algo que não necessariamente encontre resposta, adequação e muito menos solução. Não interessa ao ator resolver o enigma de sua personagem, seu ofício é reverberar

fato o próprio sentido que temos de nós mesmos e nossa conexão com os outros, tudo isso devemos à memória, à capacidade de nossos encéfalos de registrar e armazenar nossas experiências. A memória é o cimento que une nossa vida mental, o arcabouco que mantém nossa bistória pessoal e torna possivel crescermos e mudarmos ao longo da vida. Quando a memória é perdida, como na doença de Alzheimer, perdemos a capacidade de recriar nosso passado e, em conseqüência, perdemos a conexão com nós mesmos e com os outros". In: SQUIRE, (2003). 
seus mistérios em si. E para isso a potência das imagens é fundamental.

Ela também nos diz que é de noite e que é nas noites que ela passa horas ao pé da porta olhando, esperando, divagando (e bem sabemos que o gerúndio nos coloca ao sabor do Tempo. $\mathrm{O}$ gerúndio é o feitor do Tempo que nos arrebata e que tira nossos pés do chão). Essa imagem me parece muito concreta de tão poética. É fácil e emocionante visualizar essa mulher ao pé da porta de uma casa em um campo com a escuridão ao seu redor e sua face banhada pela luz indireta que vem do interior de sua casa e pelo brilho das estrelas e quem sabe pela luz, essa também indireta, de uma lua que desavisada passa por ali a espiar tal silhueta.

A vastidão de sua visão se encontra com a vastidão de seus pensamentos e desse encontro nascem imagens. Imagens, somente imagens que agora, depois do "grande" acontecimento (a volta do irmão), são por ela descritas. Mas ao mesmo tempo, temos a sensação de que ao descrevê-las ela as vivencia como se elas estivessem acontecendo nesse exato momento. E lá longe tem um bosque, um típico bosque das fábulas, um bosque escuro e desconhecido...

Ela e as outras moram em um lugar longe da agitação da cidade, local propício para se perder em si mesma, ou talvez para se encontrar... Ali nada desvia sua atenção. Ela está em estado de concentração, sempre. Uma concentração ao mesmo tempo poética e traiçoeira. Na fronteira entre loucura e sanidade, no turbilhão de imagens.

É curioso notar que essa dica, a dica da coisa imaginada, é também verbalizada conscientemente no primeiro texto da peça. A Filha mais Velha diz,

Eu estava aqui, em pé, como eu sempre estou, como eu sempre estive,

imagino isso, 
eu estava aqui, em pé, e esperava que a chuva chegasse, que ela caísse sobre o campo, sobre as plantações, e sobre o bosque, e que ela nos acalmasse,

Esse "imagino isso" é uma chave que será utilizada por todas as cinco personagens durante a peça. Elas, de certo modo, sabem que muito imaginaram nesses anos de espera. Mas saber disso não faz com que elas tenham um distanciamento crítico que certamente faria com que se abalassem menos quando o "fato" aconteceu, ou seja, a chegada do irmão frustrando todas as suas expectativas. Saber de algo não significa compreendê-lo além da razão. A razão diz, "imagino isso", mas a alma não encontra nessa construção, nessa auto-percepção do eu, conforto nem alívio. Saber-se iludido não extermina a ilusão necessariamente.

Elas "imaginam isso" e, de certo modo, esse ato de imaginar é que as mantém vivas, porém vivas na ou pela ilusão. Os fatos são gerados na mente e são tão fortes que para elas é como se eles se tornassem experiências concretas, experiências físicalizadas. É como se a imagem adquirisse uma massa corpórea externa a elas e sua percepção as introduzisse novamente em seu corpo psicofísico.

Eu estava em minha casa e esperava que a chuva chegasse.

Eu olhava o céu como eu faço sempre, como eu sempre fiz,

Tecnicamente uma das maneiras que Lagarce encontra para nos dar a dimensão de que seus personagens estão em um espaço-tempo suspendido, uma vez que elas esperam há muito tempo, é seu uso dos tempos verbais. Logo no início da peça $\mathrm{A}$ Filha mais Velha, em seu solilóquio, em uma única frase utiliza três tempos verbais distintos. "Eu olhava o céu" pretérito imperfeito, "como faço sempre", presente contínuo que nos leva ao futuro, "como eu sempre fiz", pretérito contínuo que nos leva ao passado, a todo o passado. Essa personagem se coloca, dessa forma na dimensão do Tempo absoluto. Ela sempre esteve e 
sempre estará ali esperando que a chuva chegue. Ela se sente assim no passado, no presente e no futuro, portanto ela é e está nesses tempos, ela está no próprio Tempo. No momento da narração, o momento em que a peça se nos apresenta, ela está em suspensão. Ela está imersa em sua dimensão íntima. $\mathrm{Na}$ atemporalidade.

O momento da narração, o momento em que a peça existe é o momento em que a personagem começa a perceber que se iludiu durante todo o tempo de espera e agora, sem chão, mas com a experiência viva em seu corpo, procurará se restabelecer não mais como era, mas sim através da transformação que a experiência gerou. E para isso o autor joga com os tempos verbais intensificando o estado de suspensão e de dilatação, próprio ao devaneio, alheio às cronologias.

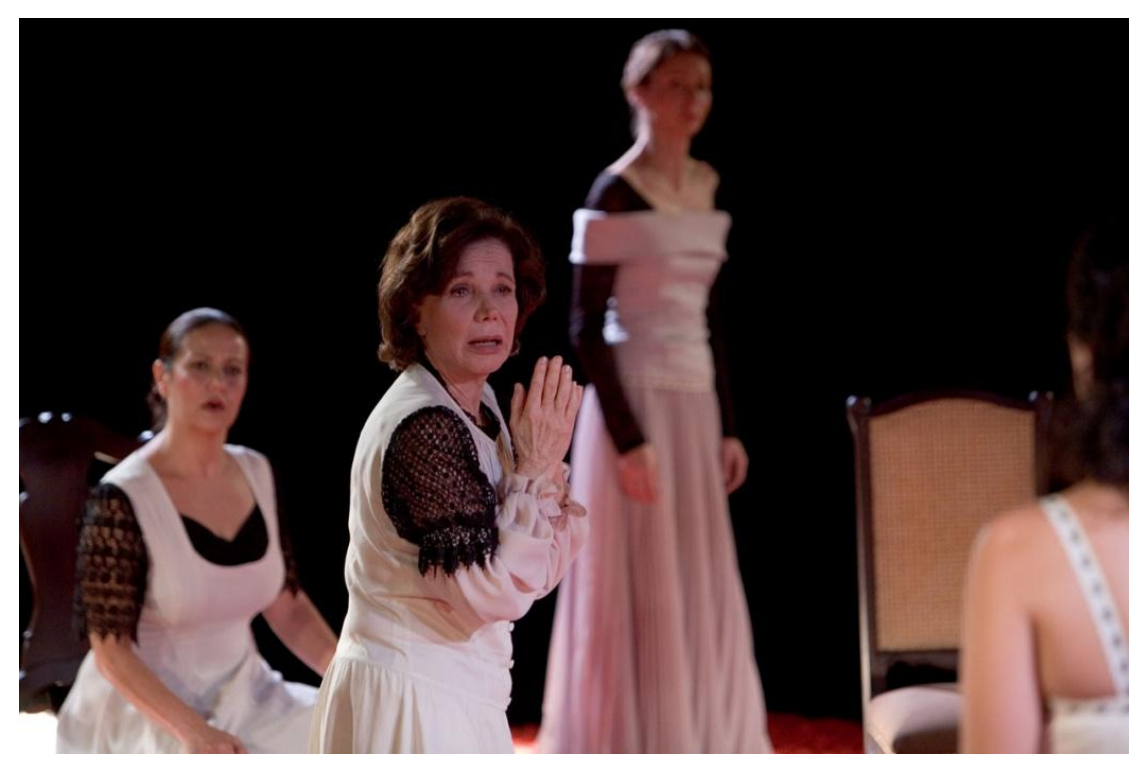

Miriam Mehler como A Mais Velha de Todas contando a sua "versão das coisas".

Esse uso do tempo verbal constrói um caminho de acesso para que a atriz compreenda e alcance esse espaço-tempo dentro de si. Compreendendo essa dimensão temporal que já é dada pelo autor (ou seja, trata-se de um material objetivo para se trabalhar), ela terá balizas concretas para poder alcançar o estado de latência 
subjetivo da personagem que é o propulsor das imagens e sensações que a inércia da espera gera no indivíduo.

Junto ao tempo verbal a própria extensão do solilóquio oferece ao ator a possibilidade de compreender em si o fluxo de pensamento da personagem. Porque se trata de um fluxo de pensamento que é verbalizado. Não nos esqueçamos que Lagarce é influenciado por Beckett que por sua vez sofreu influência de Joyce que criou um novo paradigma para a linguagem literária quando escreveu "Ulisses" e "Finnegans Wake". Nessas duas obras o fluxo de pensamento, expressado em forma literária com a invenção de novos signos de linguagem, abriu a possibilidade para que o artista encontrasse meios de externalizar imagens concernentes à interioridade. Para isso ele criou uma nova escrita apoiada em novos signos. Ou seja, expressamos a organicidade através da artificialidade.

Nesse texto, os personagens de Lagarce estão em um looping mental, e a fala longa, o material pensado que é verbalizado, aliado ao jogo do tempo verbal, servem como ferramentas objetivas para que o ator encontre em si o estado psíquico da personagem.

Esperava...

Será que eu nunca deixei de esperar?

(E na minha cabeça, ainda, ficava pensando nisso: será que eu nunca deixei de esperar? e isso me fez rir, rir de me ver assim.) 


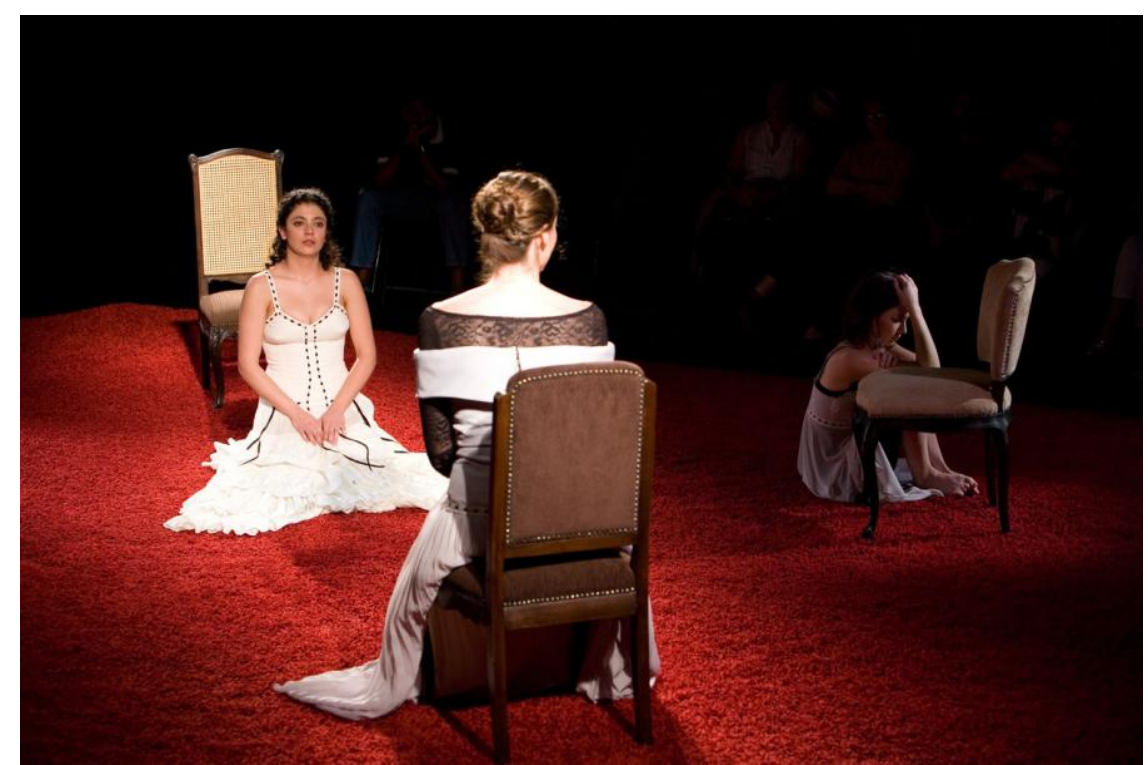

Marina Vieira, Carolina Fabri e Juliana Pinho como A Mais Nova, as três irmãs.

Interessante notar que a personagem só se questiona sobre a espera depois que o fato aconteceu: seu irmão chegou, mas... A espera então acabou? O que eu posso fazer agora que não espero mais? Sei fazer alguma outra coisa? O sujeito, assim, nos revela que algo de novo o surpreendeu. Algo dentro de si se move, ele por alguns instantes sai da inércia, tenta compreender o novo acontecimento, tenta se entender frente ao novo fato. Posso mesmo dizer que toda a peça se dá nesse instante em que algo se move dentro das personagens. Nesse instante em que buscamos nos compreender novamente. A experiência transforma-nos irremediavelmente. Ela desequilibra os alicerces sólidos sobre os quais nos acostumamos a viver. Ela transforma tanto o mundo interior quanto o mundo exterior. Nada mais é o que foi. Nada mais é o que teria sido se minhas expectativas fossem concretizadas. A experiência de fato ocorre naquele espaço potencial que dissemos acima. Nesse lugar "entre" a interioridade e a externalidade.

E ao se deparar com a questão, a personagem em um átimo furtivo percebe o patético que sempre operou em si. Ela ri de si mesma. Ela ri de sua condição. Ela ri de sua tolice. Mas 
mesmo assim esse riso, esse humor que só uma inteligência sensível é capaz de ter, não fará com que se liberte de seu fracasso, não é sinal absoluto de salvação. Porque esse rir de si mesma seria apenas uma constatação, não necessariamente uma alavanca segura para um processo de transformação.

(e ainda aí, parece, comecei, mais uma vez, a sorrir de mim mesma, de me ver assim, de me imaginar assim, e sorrir assim de mim mesma à beira de lágrimas, $\mathrm{e}$ tive medo de afundar)

Sorrir à beira de lágrimas. Consciência emocionada. O máximo da percepção racional atada ao máximo dos processos anímicos. Rir e chorar ao mesmo tempo, quando o indivíduo se depara com a tragicidade de sua condição. Estabelecendo o patético. "E tive medo de afundar" imagem preciosa, o medo da queda, o medo de perder aquilo que sempre a norteou, medo da perda de princípios, medo moral, medo de se deparar com o desconhecido, medo do abismo. Se deparar com o medo é sinal que alguma coisa se move, que o se afundar possa ser inevitável e talvez ali encontre algo revitalizante.

Aqui também é curioso notar que a personagem consegue sair de si para se olhar. Ao ver-se pelo lado de fora, ao se separar de si mesma por alguns instantes, ela estabelece contornos bem delineados sobre sua condição psicofísica. Em sua solidão, uma vez que ela não tem o outro para defini-la através de sua visão (a visão do outro), é necessário o exercício para tentar sair de si e talvez reter alguma concretude. Essas cinco mulheres vivem juntas, mas não necessariamente convivem e estabelecem uma relação de troca efetiva e repleta de afeições. E nessa mesma sequência que começa com

Eu olhava a estrada...

Evai até

Todos esses anos que nós tínhamos vivido à espera dele e perdidas sem fazer outra coisa que não fosse esperar por ele, sem poder obter nada, nunca, sem ter outro objetivo que não fosse esse, 
e eu pensava, nesse dia preciso, no tempo que eu poderia ter passado longe daqui, fugindo daqui, no tempo que eu poderia ter passado numa outra vida, num outro mundo, ideia minha, sozinha, sem vocês, as outras aí, sem vocês outras, todas,

todo esse tempo que eu poderia ter vivido diferentemente, simplesmente, sem esperar, sem esperar mais, ter me soltado de mim mesma.

Como Lagarce quebra em sua estrutura a relação de causaefeito quando embaralha os tempos verbais, ouvimos a Filha mais Velha contar às outras que antes dele chegar ela já pensava que todo aquele tempo de espera foi em vão e pensava na possibilidade de sair dali, ir para um outro lugar, sozinha, viver uma vida diferente. Mas na verdade ela nos conta isso depois do acontecido, seu irmão já chegou, é possível que esse pensamento só ocorra a ela porque seu irmão chegou e suas expectativas foram por água abaixo. Ou talvez não. Não importa.

O que interessa é que mesmo a possibilidade de ida, de viver uma outra vida, "longe daqui", é um processo ilusório, é apenas uma ideia, e ela sabe disso, "ideia minha”. Sua imaginação a transporta para outros lugares, mas seu corpo continua onde está, onde "sempre esteve", "olhando a estrada". A força da imagem "estrada" para esse ser que se sente aprisionado na espera é contundente. Mas tem apenas a contundência de fazer com que mais uma vez ela "imagine isso", imagine a possibilidade de fugir dali, sem olhar pra trás.

"Ter me soltado de mim mesma". É realmente emocionante notar a dimensão dessa frase quando entendemos que a personagem na verdade se encontra presa dentro de si mesma. Presa às suas imaginações ilusórias, presa à espera que ela criou como sendo vital para si, presa às recordações selecionadas por ela para criar um sentido para sua vida, presa, enfim, em sua subjetividade desprovida de corpo. Lagarce, assim, nos escarra o argumento que esses processos da subjetividade que a primeira vista podem nos oferecer chaves para a liberdade, podem ser, na 
verdade, os carcereiros que nos mantém algemados em celas sombrias banhadas exclusivamente pela esperança, uma nesga de luz que atravessa a janela e que nos mantém olhando para ela o tempo inteiro de nossas vidas. Gastamos a energia da vida ao olhar para essa nesga de luz. E talvez essa seja a maior tragédia da condição humana.

\footnotetext{
Esperava a chuva, esperava que ela caísse, esperava, como, de um certo modo eu sempre esperei, esperava e eu o vi,

eu esperava e foi aí que eu o vi, esse daí o cacula, fazendo a curva do caminho e subindo em direção de casa, eu esperava sem esperar nada de preciso

e eu o vi voltar, esperava como eu espero sempre, há tantos anos, sem esperança de

nada, e foi nesse exato momento que ele apareceu, e que eu o vi.
}

A Filha mais Velha então nos conta que o acontecimento mais importante da vida delas acabara de se realizar. Ela esperava e de repente o viu, seu irmão caçula, subindo em direção de casa. É interessante notar que nesse pequeno trecho de seis linhas, ela usa 11 vezes a palavra "esperava" com suas variações entre espera e esperança, e entremeada por essa profusão de esperas ela diz 5 vezes "e en o vi". É como se ela tivesse que dizer a ela mesma que aquilo que estava experimentando, ou seja, seus olhos de fato viam seu irmão voltar, era realidade e não mais uma criação mental. Seus olhos viam sim, no meio da longa espera, no meio da eterna esperança. De repente seus olhos viam com olhos de ver algo desejado, a retina estava impregnada por uma imagem extraída do mundo exterior e essa imagem era de fato o seu irmão. Difícil acreditar, mas, sim, ela o via. Não havia dúvida. Ela que sempre olhava a estrada que poderia levá-la para um lugar distante, nesse dia essa mesma estrada de ida trazia de volta seu irmão. A mente demora em compreender a relação entre fato imaginado e fato concreto, porque o fato concreto geralmente é de uma objetividade atroz se comparado aos caminhos tortuosos da imaginação. A imaginação é estética, sua palheta tem infinitas 
combinações de cores e de formas. O fato é cru, um soco no estômago, uma pedra no rim e sua beleza só percebemos depois de acontecido.

Um carro vem deixá-lo e ele caminha os últimos cem metros, bolsa jogada sobre o ombro, em minha direção.

Olho para ele vindo em minha direção, em minha direção, em direção de casa.

Olho para ele.

Mais a frente, quando sabemos que o irmão chegou e caiu e "agora" está inerte em seu quarto, essa "bolsa jogada sobre o ombro" ganha importância. As personagens várias vezes durante a peça farão referência a esse objeto. Ele será um porto seguro em suas narrações. Porque se trata de um objeto que ele levou de casa quando dali ele saiu há muito tempo. Um objeto reconhecível, um objeto que a memória guardou e que agora é possível saber que era um objeto verdadeiro, não uma ilusão. É como se a identidade do irmão fosse reconhecida antes pelo objeto que carregava. $\mathrm{O}$ objeto que a memória soube preservar irretocável oferece os contornos definitivos de um rosto que poderia estar mudado, afinal muitos anos se passaram. Será que o irmão hoje seria reconhecível? Eu me lembro de seu rosto? A memória guarda coisas "corriqueiras", e parece que esquece de coisas que nosso eu julga serem importantes e fundamentais. Esse "eu" por nós criado e que parece estar sempre no controle da situação é no mais das vezes iludível. Ele se preocupa com as coisas "grandes" e se esquece que é nos detalhes, em um gesto trivial, em um objeto qualquer que muitas vezes pode-se encontrar força simbólica.

Eu não me mexia, mas tinha certeza que seria ele, tinha certeza que era ele, ele entrava na nossa casa depois de todos esses anos, assim mesmo,

nós sempre tínhamos imaginado que ele voltaria assim, sem prevenir, sem festa de boas-vindas e ele fez o que nós sempre tínhamos imaginado que ele faria. 
Paralisada pela contundência do acontecimento, sua mente trabalha implacavelmente para encontrar sentido em tudo aquilo. Aqui vemos que a personagem conscientemente estabelece uma conexão entre o fato imaginado e o que de fato aconteceu. Ela sempre esperou que o irmão voltasse de repente, sem avisar. E isso de fato aconteceu, e por alguns instantes ela encontra prazer nessa constatação. Ela é tomada por uma alegria que em seguida se revela fugaz porque a sequência de ações do irmão, aos poucos, mostra a ela que a imaginação por ela criada não estava de fato "colada" à realidade. Mesmo quando a imaginação é capaz de se espelhar na realidade há algo nela que a transcende. $\mathrm{O}$ eu novamente se sente desorientado, à beira do abismo, pois não reconhece em si a verdade da situação. Isso porque

Ele olhava pra frente e caminhava calmamente sem se apressar, mas parecia que não me via esse daí, o caçula, por quem tanto esperei e perdi a minha vida esperando

-perdi, sim, não tenho dúvida, e de uma maneira tão inútil, agora, a partir de agora, eu sei, que eu a perdi -

Ele não a via. Ela o olhava profundamente e ele não a via. Ela o olhava em si, dentro de si, mas ele parece que só olhava para ele mesmo. Não a via, não via nada a sua volta. Ele não fez nenhum gesto, não sorriu, não falou nada, e aí a personagem grita sua terrível constatação: sua espera foi inútil, ela sabe que perdeu a vida nessa espera, e ela de nada adiantou.

O choque frente a essa constatação faz com que a psique se embaralhe na mesma medida que uma frase simples e objetiva ressoe em sua mente com força de "verdade". Ela perdeu a sua vida. Tudo foi em vão, e ela percebeu isso, "agora”. Essa verdade que só a experiência aguda nos demonstra. Quando a experiência é vivenciada na ponta do instante ela se presentifica de tal maneira que é impossível ainda trabalhar com o auto-engano. 
O indivíduo no mesmo tempo que se sente perdido, desequilibrado, sem contornos identificatórios, nesse momento começa a reaprender-se, a reorganizar-se frente à constatação inequívoca de sua tragédia particular e íntima. Ela perdeu a sua vida por causa de uma ilusão. Ela perdeu a sua vida porque ela não viveu a vida. Ela se esqueceu de seu corpo, ela se esqueceu de seus desejos, ela se esqueceu de seus hormônios, ela se esqueceu de experimentar a relação com os outros, com as outras coisas, ela se deixou seduzir por si mesma, ela se bastou.

Esse processo de afirmação amparado no auto-engano anuncia a tragédia. Ensimesmado, ele cria sim universos, personas, contextos, mas que são, na verdade, criações ilusórias, criações desprovidas de imagens simbólicas.

esse daí, o caçula, voltando das suas guerras, eu o vi enfim e em mim nada mudou, fiquei espantada com a minha própria calma, nenhum grito como eu tinha imaginado que eu daria, que vocês dariam, nossa versão das coisas, nenhum berro de surpresa ou de alegria, nada

Toda enunciação trágica é formulada através de um espanto. O homem se espanta quando algo além de sua imaginação acontece. Se ele não havia sequer imaginado como ele pode lidar com esse dado novo, de absoluta surpresa? Ainda mais se o acontecimento de tão implacável não transforma nada, ou pior, mantém as coisas como elas estão: “e em mim nada mudou".

A volta do irmão nada alterou porque ele não voltou como elas tinham imaginado. Podemos mesmo dizer que para elas ele não voltou, porque a coisa imaginada nesses termos tem tanta força que se impõe como realidade. Quem voltou foi “outro”. Ele não fez nada do que esperei, e nós não fizemos nada que havíamos imaginado.

E o mais terrível é que a personagem tem consciência disso. O espanto só acontece porque compreendemos algo que não fazia parte de nosso repertório. O espanto é por assim dizer 
um preenchimento de uma lacuna no pensamento. Ficamos espantados até estabelecermos ponte de acesso ao novo material que preenche um vazio, mas um vazio que parece que já estava pronto para ser preenchido. É como se a psique criasse sorrateiramente uma estrutura vazada e esperasse sabiamente o momento em que ela seria preenchida com o concreto do acontecimento inusitado.

A Filha mais Velha, em seguida ao ocorrido já formula uma frase crucial que é uma das chaves para compreendermos a linguagem que Lagarce utiliza para revelar os processos mentais de significação advindos das personagens como "falas": "a nossa versão das coisas". Ela sabe que cada uma delas tem uma versão dos fatos, dos fatos do passado mais distante, da época em que ele ainda vivia com elas, e dos fatos recentes, ou seja, todas, de um certo modo, o viram se aproximar, chegar e cair na sala sem nada fazer. O que é interessante é que mesmo tendo consciência que a imaginação pode pregar peças ilusórias e tendo consciência que o depoimento pessoal sempre será apenas uma visão das coisas, uma versão dos fatos, ela não está livre desse espanto. Ela sente sua tragicidade. A razão, com sua lógica organizada a ponto de criar uma equação frasal pertinente, "a nossa versão das coisas", não consegue evitar o abalo, o choque, porque algo mais fundo é tocado nesse momento que necessariamente desarticulará os processos racionais de compreensão, tornando-os esvaziados.

Eu via, ele andando em minha direção e pensava que ele estava de volta e que nada ia mudar na minha vida, que foi engano meu.

Solução nenhuma.

Ela já sabe que tudo foi um auto-engano e que ela e as outras mulheres da família colocaram as suas vidas à disposição de uma crença que foi criada em suas imaginações ensimesmadas. A volta do irmão, assim, não soluciona nada, pois não é nesse acontecimento que ela encontrará subsídios para satisfazer-se. O problema não está nele, e sim nelas. Ele foi e voltou de suas 
"guerras". Ele foi viver a sua vida simplesmente, enquanto que elas deixaram de viver as suas. $\mathrm{O}$ irmão assim não solucionará nada, dentro dela nada mudou, a não ser a constatação de que tudo não passou de um engano, um erro de opção, uma má escolha e que ela de alguma forma terá que lidar com suas consequências.

Assim, a peça acontece frente aos olhos do espectador nesse tempo dilatado em que o indivíduo tentará juntar os cacos que sobraram frente ao reconhecimento da escolha feita. E talvez, quem sabe, acessar seu self sem truques atenuantes e sem intermediações ilusórias por ele mesmo inventadas.

É dessa forma que a Filha mais Velha termina o primeiro solilóquio da peça. Lagarce faz desse primeiro solilóquio um prólogo análogo aos prólogos das tragédias gregas. Aqui já temos de antemão um resumo do que a peça tratará. Todas as questões das personagens serão desdobramentos desses pensamentos que esse personagem nos conta em sua primeira fala. Cada personagem de alguma forma, como a Filha mais Velha, também tentará desfazer o nó criado no fio de sua interioridade. A forma com que o autor utilizará a linguagem também aqui já está decodificada. O mundo interior dessas personagens aqui será deflagrado por intermédio de uma torrente de palavras que se repetem buscando esclarecer para elas mesmas a verdade de seus significados. Elas lutarão contra elas mesmas, contra os processos de significação conformados nelas mesmas, elas tentarão enxergar as coisas não somente a partir de seus pontos de vista, mas levando em conta seus campos de visão ${ }^{4}$.

\footnotetext{
${ }^{4} \mathrm{O}$ exercício Campo de Visão, que constantemente venho sistematizando, tem como um de seus objetivos principais fazer com que o ator criador compreenda que para criar algo não interessa o seu ponto de vista e sim a abrangência que sua vista alcança ao enlaçar-se com outras visões, com outros corpos, com outras impressões.
} 


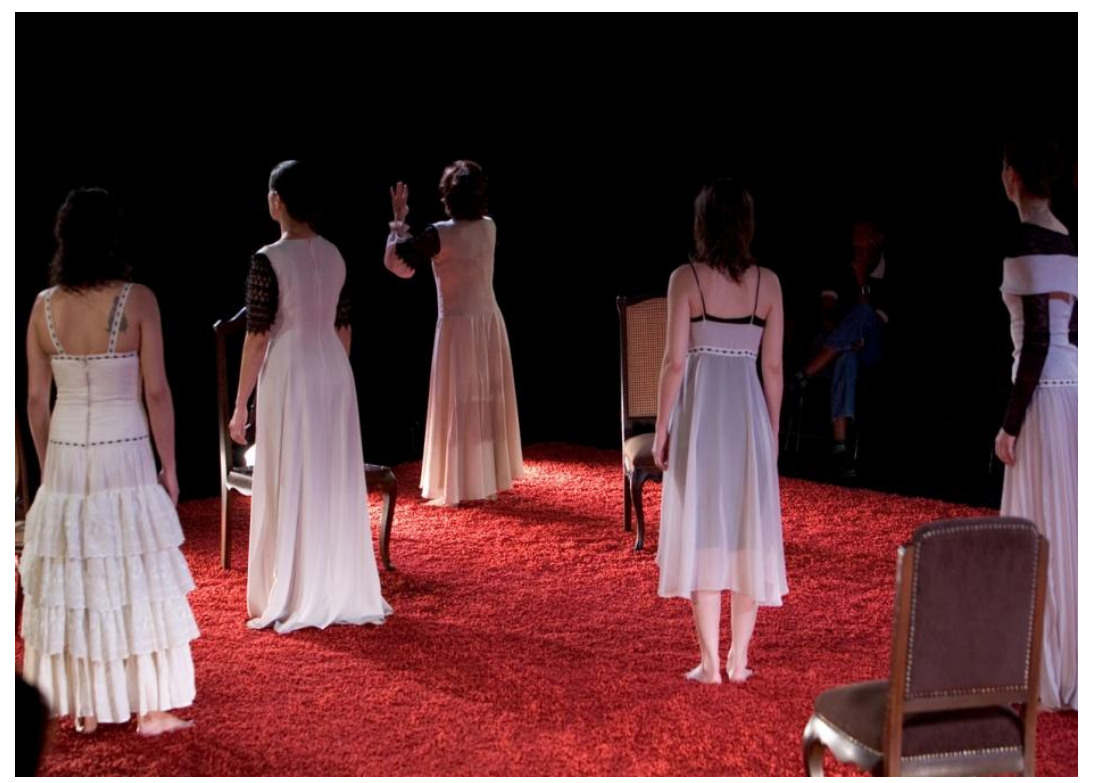

BIBLIOGRAFIA:

AB'SABER, Tales A. M. O sonbar restaurado: formas de sonbar em Bion, Winnicott e Freud. São Paulo, Ed. 34, 2005.

BERRETINE, Célia. A linguagem de Beckett. São Paulo, Perspectiva, 1977.

CALLEGARO, Marco Montarroyos. "Implantes da memória". In: Psique Ciência e Vida. Ano 1, nº 7, Editora Escala. p. 37.

GIL, José. O espaço interior. Lisboa, Editorial Presença, 1993.

HILLMAN, James. Psicologia arquetípica. São Paulo, Cultrix,1988.

JOYCE, James. Finnegans Wake. Versão: Donaldo Schüller. Porto Alegre, Ateliê Editorial, 1999.

JUNG, Carl G. Os arquétipos e o inconsciente coletivo. Petrópolis, Vozes, 2000.

MITHEN, Steven. A pré-história da mente. São Paulo, Ed. Unesp, 2002.

SQUIRE, Larry. Memória: da mente às moléculas. Porto Alegre, Artmed, 2003.

STANISLÁVSKI, Constantin. A construção da personagem. Rio de Janeiro, Civilização Brasileira, 1989.

Abstract: This article is an analysis of the play I was in my house and waited for the rain to come, by Jean-Luc Lagarce, focusing the memory and the imagination as essential elements for the dramaturgical construction and also for the actresses' task to build their characters.

Key-words: contemporary drama; memory; imagination and theatrical language. 